\title{
Short Communication: MADS-box genes expression in seedlings of Elaeis guineensis Jacq. resistance to Ganoderma boninense
}

\author{
RAHMAH HAYATI ${ }^{1}$, LISNAWITA ${ }^{2}$, ERMAN MUNIR ${ }^{3}$, MOHAMMAD BASYUNI ${ }^{4, \bullet}$ \\ ${ }^{1}$ Doctoral Program in Agricultural Sciences, Faculty of Agriculture, Universitas Sumatera Utara. Jl. Dr. A. Sofian No. 3, Kampus USU Padang Bulan, \\ Medan 20155, North Sumatra, Indonesia \\ ${ }^{2}$ Program of Agrotechnology, Faculty of Agriculture, Universitas Sumatera Utara. Jl. Dr. A. Sofian No. 3, Kampus USU Padang Bulan, Medan 20155 , \\ North Sumatra, Indonesia \\ ${ }^{3}$ Department of Biology, Faculty of Mathematics and Natural Sciences, Universitas Sumatera Utara. Jl. Bioteknologi No. 1, Kampus USU Padang Bulan, \\ Medan 20155, North Sumatra, Indonesia \\ ${ }^{4}$ Department of Forestry, Faculty of Forestry, Universitas Sumatera Utara. Jl. Tri Dharma Ujung No. 1, Kampus USU Padang Bulan, Medan 20155, \\ North Sumatra, Indonesia. Tel./fax. +62-61-8201920, `email: m.basyuni@usu.ac.id
}

Manuscript received: 27 October 2020. Revision accepted: 26 November 2020.

\begin{abstract}
Hayati R, Lisnawita, Munir E, Basyuni M. 2020. Short Communication: MADS-box genes expression in seedlings of Elaeis guineensis Jacq. resistance to Ganoderma boninense. Biodiversitas 21: 5805-5810. Advances in molecular technology were allowed the molecular studies of the flowering genes to expected to be used to predict Elaeis guineensis fruit production. This study aims to identify the genetic structure associated with flowering genes, belonging to the MADS-box gene family of oil palm to Ganoderma boninense susceptible and resistance types. Different length of expressed genes was identified the single band pattern. Based on UVITEC-1D methods, all populations detected expression in primer EGGLO and EGDEF. Moreover, SS, SA, RA were not expressed in primer EGSQUA, EGAGL2, and EGAG. GENEALEX results, 5 sets of MADS-box family markers showed Na values was 2.20 to 3.00 , and He values was 0.40-0.67. Higher PIC $=0.82$ was found in RA and SA populations. The dendogram described clustering based on genetic distances with two clusters. The first cluster was described as resistant asymptomatic and symptomatic population. Furthermore, the second cluster consisted of two clustering susceptible asymptomatic and symptomatic populations, separately. This phenomenon is likely to be the sampling rate and the addictive nature of parent crossing derivatives.
\end{abstract}

Keywords: Elaeis guineensis, GENEALEX, MADS-box gene expression, oil palm, PIC

Abbreviations: RS: Resistance symptomatic, RA: Resistance asymptomatic, SS: Susceptible symptomatic, SA: Susceptible asymptomatic

\section{INTRODUCTION}

The incredible Elaeis guineensis Jacq. productivity was underlined with the reality of the crop from one-third of the world plant, based on the production of fats and oils. Therein the oil palm production was occupation 75.7 million tons in 2017, and export amounted to 1.53 million tons of USD 819.26 million in 2020. It was recorded to have increased by $14 \%$ and $27 \%$ in terms of market share value compared to the same period in 2018-2019 (Subagyono 2020; Shahbandeh 2020). Growth parameters of oil palm were survival rate, plant heights, leaf lengths, leaf width, stem girth, and total fruits (bunches) (Soltis and Soltis 1989; Misron et al. 2020). The total fruits are one of the main parameters of oil palm production. Commonly, oil palm production related to the number of fruits can be determined from the beginning of the flowering phase as the initial stage of fruit formation (Adam et al. 2011; Abraham-Juarez et al. 2020; Alabi et al. 2020; Noushini et al. 2020).

Advances in molecular technology were allowed the molecular studies of the flowering genes that play a role in flowering (Santos et al. 2020; Uguru et al. 2020). In most plants, the flowering process is controlled by many genes, such as SQUA, AGL, GLO, AG, and DEF genes that are mutually reliable (Singh et al. 2020). The structural character from E. guineensis to the MADS-box genes, namely SQUAMOSA, DEFICIENS, GLOBOSA, AGAMOUS, and AGL2 subfamily (Adam et al. 2006). On oil palm, the molecular development of flowers is still limited. Singh et al. (2020) have been reported oil yield was controlled alleles type II MADS-box genes (SHELL) to impact of presence that thickness from endocarp, shell, and fruit of kernel. Recently, Li et al. (2020) have been reported EgMADS21 was expressed to early mesocarp development stages from oil palm fruits to a negative correlation. Furthermore, the MADS-box genes remain considered as the most potential ancestor of sweet potato and transcription factors regulate the floral organogenesis in lotus (Giovannoni 2007; Zhu et al. 2020; Lin et al. 2020). The SQUA, GLO, and DEF genes were included in the MADS-box gene occupied with sepals, petals, and stamen contents. The MADS-box gene encodes the family's major transcription factors regulating development in higher plants, including flowers and fruits (Saedler et al. 2001). 
The function of the MADS-box gene was determined as a regulator that controls plant development pathways (Alvarez-Buylla et al. 2000). However, the commercial oil palm germplasm in Indonesia aimed at seeds that resistant to diseases such as Ganoderma. G. boninense and $G$. sinense can stunt growth and fruit production in oil palm plants from the age of 5 to 25 years, wherein, the oil palm cannot produce optimally (Hayati et al. 2020). $G$. boninense has interfered with the flowering and formation process of oil palm fruits (Shariffah-Muzaimah et al. 2020).

Putranto et al. (2016) has been reported six upregulation genes, i.e. EgCHI1, EgVIR-1, EgVIR-2, EgIFR-2, EgMT1 , and EgSPI-2 as potential positive biomarkers for oil palm of moderate tolerant to Ganoderma. Sarpan et al. (2020) has been reported the EgDEF1 gene was expressed for clonal abnormality in the epigenetic phenomenon and linked for hypomethylation to transposable elements. However, in general, there is little knowledge about the function of the flowering gene in Ganoderma pathogenresistant plants. This study aims to identify the genetic structure associated with flowering genes, belonging to the MADS-box gene family from E. guineensis fruits variety resistance to $G$. boninense susceptible and resistant plant types. The finding of genetic structure fruit may present the genetic resources for further optimization of oil palm breeding.

\section{MATERIALS AND METHODS}

\section{Plant materials}

The materials were used in this study from the plant crossing Dura $\times$ Pisifera varieties from Elaeis guineensis belong to Socfindo derived in Bangun Bandar-Serdang Bedagai, Indonesia, located at $3^{\circ} 18^{\prime} 43^{\prime \prime} \mathrm{N} 99^{\circ} 00^{\prime} 23^{\prime \prime}$ E. One series of plant crosses from Ganoderma boninense experimental genetic material in the field (2002 planting years). The plantation area was $50 \mathrm{ha} /$ block, wherein sixty plants/plot per one cross. The spacing was $9 \times 9 \mathrm{~m}$ (equilateral triangle) with a total crop of 144 plants/ha. Then, the fruits were harvested 2-3 months after flowering. A total of fruits were used in two types (resistance and susceptible) with 30 replications for each population. The sample plants used were in standard conditions to find uniformity, the fresh bunches from the plants used were growth flat soil and not ditch (the presence of stagnant water was thought to be not only a factor of $G$. boninense diseases). The genetic material for the Ganoderma trial in the field was fruit tissues from plants that were still produced from 17 years old (block 35). Observation of resistance to Ganoderma followed the previous procedures, namely genetic trial, parental garden, specific Ganoderma trial, and early screening test (Breton et al. 2009). Type of fruits was classified from symptomatic and asymptomatic oil palm plants against Ganoderma pathogen (Table 1), namely Resistance symptomatic (RS); Resistance asymptomatic (RA); Susceptible symptomatic (SS); and Susceptible asymptomatic (SA) were previously studied (Hayati et al. 2021).

\section{DNA extraction}

DNA isolated by using the cetyl trimethyl ammonium bromide (CTAB) method (Basyuni et al. 2017) with modified with polyvinyl pyrrolidone (PVP). Firstly, the fruit fresh bunches tissues (500 mg of mesocarp and kernel per sample) from E. guineensis were ground in liquid nitrogen with a mortar, and then $0.1 \mathrm{~g}$ of PVP was added. Then, $5 \mathrm{ml}$ of CTAB was added to the sample and incubated at $65{ }^{\circ} \mathrm{C}$ for 30 minutes. Furthermore, 1 volume of chloroform: isoamyl alcohol $(24: 1 ; \mathrm{CI})$ was added, and the samples were centrifuged at $14,000 \mathrm{rpm}$ at $4{ }^{\circ} \mathrm{C}$ for 20 seconds. This step was repeated three times.

The supernatant was collected and added 1 volume of cold isopropanol, then incubated at $-20{ }^{\circ} \mathrm{C}$ for 30 minutes. Thus, the samples were centrifuged at $14,000 \mathrm{rpm}$ at $4{ }^{\circ} \mathrm{C}$ for 10 minutes. This dried pellet was added with $500 \mu \mathrm{L}$ TE $\mathrm{pH} 8,1 / 10$ volume of $\mathrm{NaCH}_{3} \mathrm{COO}_{3} 3 \mathrm{M} \mathrm{pH} 7$ (cold), and 2 volumes of ethanol absolute (cold) and incubated overnight at $-20{ }^{\circ} \mathrm{C}$. The next following day, the dried pellet was washed with $400 \mu \mathrm{L}$ of $70 \%$ ethanol (cold) and centrifuged at $14,000 \mathrm{rpm}$ at $4{ }^{\circ} \mathrm{C}$ for 5 minutes. One hundred $\mathrm{ml}$ of double-distilled water $\left(\mathrm{ddH}_{2} \mathrm{O}\right)$ and $1 / 10$ volume RNAse were added to the dried pellet, and then the sample was incubated at $37{ }^{\circ} \mathrm{C}$ for 1 hour. The quality and quantity tests were used in the absorption spectrum (220$750 \mathrm{~nm}$ ) with NanoDrop 1000 (Wilmington DE, USA).

\section{Polymerase chain reaction (PCR)}

MADS-box primers were selected refer to Table 2 (Adam et al. 2006). One reaction contained $2.5 \mu \mathrm{L}$ SappireAmp Fast PCR Master Mix (2X Premix), $0.5 \mu \mathrm{M}$ Forward and Reverse primer and $100 \mathrm{ng}(1.5 \mu \mathrm{L})$ DNA, and $5.0 \mu \mathrm{L} \mathrm{dH} 2 \mathrm{O}$, wherein $10 \mu \mathrm{L}$ reaction volume. PCR was recognized under the condition to denaturation at $94^{\circ} \mathrm{C}$ for 2 minutes, 30 cycles at $94^{\circ} \mathrm{C}$ for 30 seconds, annealing at $55-60^{\circ} \mathrm{C}$ for 60 seconds, the extension at $72^{\circ} \mathrm{C}$ for 3 minutes, and through the final extension at $72^{\circ} \mathrm{C}$ for 7 minutes.

\section{Electrophoresis}

The PCR product was analyzed using electrophoresis within a 1\% agarose capsule (Lee et al. 2012). Furthermore, the GelRed was added and carried out with a UV-Transilluminator to estimate the molecular weight using UVITEC-1D (UVI-1D) software from Cambridge. 
Tabel 1. Description of material planting

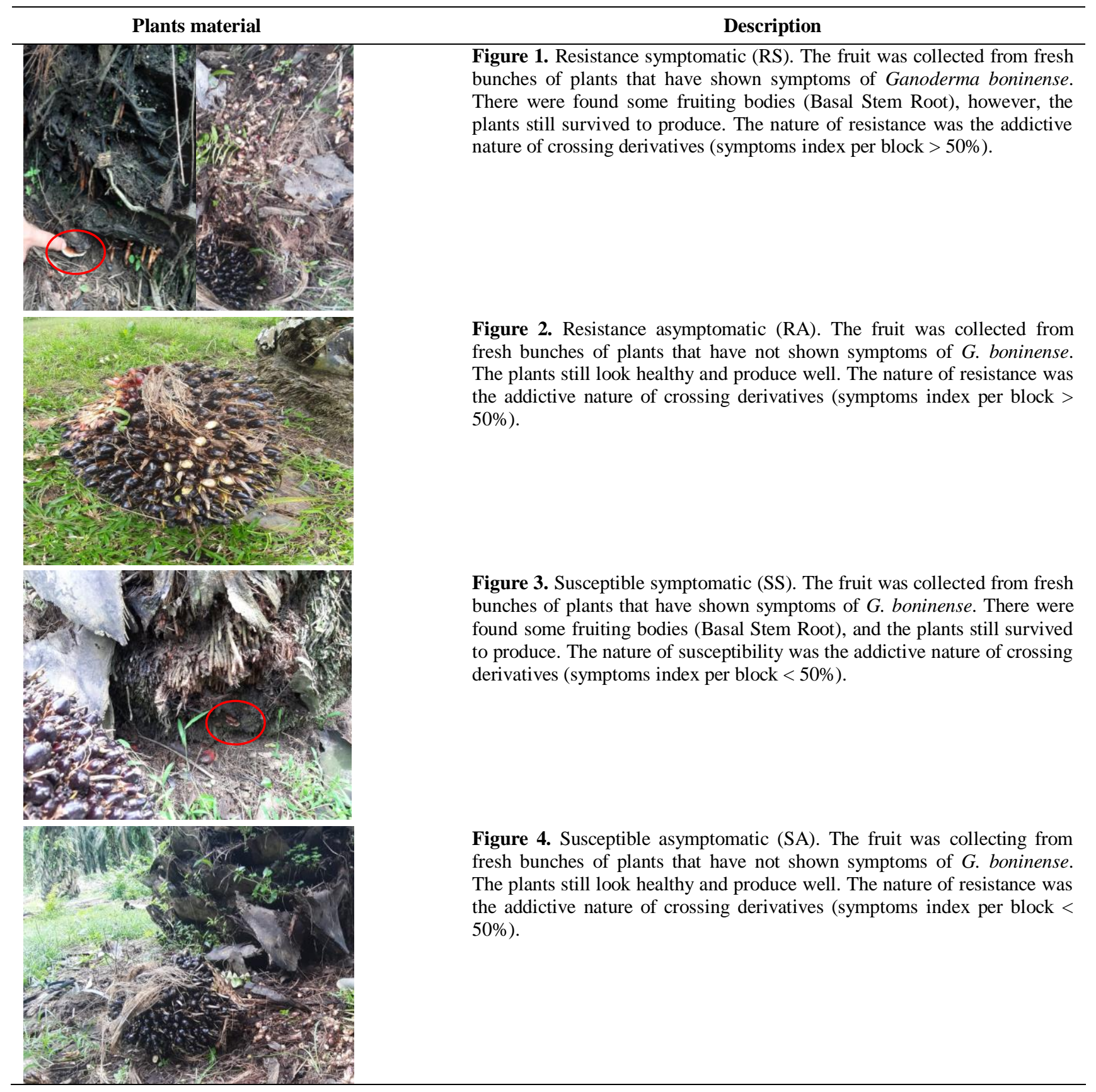

Tabel 2. Primers used to analyze the MADS-Box genes

\begin{tabular}{|c|c|c|}
\hline Primer & Primer sequences ( $\left(5^{\prime}-3^{\prime}\right)$ & Amplification (bp) \\
\hline EgSQUA & $\begin{array}{l}\text { F-AGGCACTAAACCAGCAGGCA } \\
\text { R-ACACACTTAAGGTTCCCACA }\end{array}$ & 459 \\
\hline EgAGL2 & $\begin{array}{l}\text { F-TGCAGATCTTCAACGAAAGG } \\
\text { R-TAGAATAGCTCCCTCACAGG }\end{array}$ & 471 \\
\hline EgGLO & $\begin{array}{l}\text { F-TGAGGCATTTGAAGGGTGA } \\
\text { R-ACACCAAAAGAGAAGACC }\end{array}$ & 365 \\
\hline EgAG & $\begin{array}{l}\text { F-CCTTCAGAATTCGAACAGG } \\
\text { R-GACAGGCTCCCCTCTCAGGA }\end{array}$ & 519 \\
\hline EgDEF & $\begin{array}{l}\text { F-ATCACCACGCAGACGGATAC } \\
\text { R-AGTACCATGGAGGAAGCCAA }\end{array}$ & 365 \\
\hline
\end{tabular}




\section{Data analysis}

The parameters of the genetic structures were calculated using GENALEX ver 6.502. This software was particularly in the range matrix to generate multiple types of the marker, including codominant data, haploid data, and binary of genetic data. The locus was used in codominant data sets and options and was used for all analyses. To identification the correlations among individuals in the subpopulation used to run Fis, the frequency correlations among subpopulations to Fst, and for both factors was Fit. PIC analysis was a polymorphism information content. The allele frequency data for each locus and allelic pattern across populations are described in Figures 5 and 6. F-statistics (Fis, Fit, and Fst) were estimated for each locus. The probability of being greater than zero was determined by bootstrap analysis using 1,000 replicates, with a 99\% confidence interval (Peakall and Smouse 2006). For all statistical tests, we chose a level for a significance level $* \mathrm{P}<0.001$. Each population was analyzed the number of different alleles of frequency $>0.5 \%(\mathrm{Na})$ and the genetic polymorphisms to the heterozygosity expected (He) (Avval 2017).

The clustering of genetic distinct among populations were conducted using MultiVariate Statistical Package (MVSP) Kovach computing services, UK ver 3.2, for Unweighted Pair Group Method of Arithmetic average (UPGMA) (Backeljau et al. 1996). The bootstrap was analyzed in 1000 replications for assessed nodes strength (Felsenstein 1985).

\section{RESULTS AND DISCUSSION}

\section{Results}

The expression pattern from the MADS-box genes was presented by PCR using DNA from fruit tissue. The EGGLO (GLO subfamily) genes have a role during the male and female in inflorescence to development. GLO genes (B-class) was played a generally conserved role in the determination of petal and stamen identity. To determine how and when these functions evolved is critical to the evolution of flowers. The proteins GLO necessary for stamen establishment and thus fertility. The expression was barely detected from RA and RS populations. However, the strong expression being appeared in the SS population, and similar detected in SE. Furthermore, the EGDEF genes (DEF subfamily) were detected similar to all populations. DEF subfamilies were suggested a strong coevolutionary pressure necessary to conserve the heterodimerization characteristic of the APETALA3 (AP3) protein. In the case of oil palm, it is interesting to note that the EgDEF and EgGLO genes display slightly different expression patterns. The genes have a role in the determination of stamens (Figure 5).

The EGSQUA genes belong in the SQUAMOSA (SQUA subfamily). SQUA subfamily has a terminal part of the protein and present in FRUITFULL. These genes play a role in the determination of its function and specificity of flowers at the base of the tree. EGSQUA genes are expressed in vegetative organs and determination of the identity of the floral meristem. The expression patterns were detected from SA, RS, RA populations. However, no expression in SS. The EGAGL2 genes have a role during for late stages in floral fruit development (AGL2 subfamily). The weakly expression being detected only for SS and RS populations. Thus, the function emerges restricted for reproductive fruit development from SA and RA populations. The EGAG genes have been appertained in the AGAMOUS (AG subfamily). The AGL genes were displayed in distinct patterns. In comparison with the AGL and AG subfamilies have strong coevolutionary to represent a specialization of function in flower complex. AGL and AG genes were found to be expressed in vegetative tissue. The results reported here show several identified oil palm genes has an expression pattern specific resistance and susceptible to either the populations, although no expression has been reported in some genes. For which expression was weakly detected from RS and not detection in SA. Similarly, their expression genes were a pattern (Figure 6).

The number of different alleles $(\mathrm{Na})$ were identified from 2.20 to 3.00 , whereas the heterozygosity expected (He) was $0.40-0.67$. The RA and SA populations were showed the same values of He. The data PIC was found highest polymorphism of genetic similarity among RA and SA populations $(\mathrm{PIC}=0.82$ ). Besides, not similarly, very low polymorphism was found RS and SS populations (Table 3).

Genotype frequency for loci in populations was presented by the fixation index. The Fis was shown at 1.00 from all populations, in the case was a deficiency of heterozygotes, similar to each other than with Fit value (1.00). However, Fst significant difference values were described from all locus, the range 0.273 to 0.652 (Table 4).

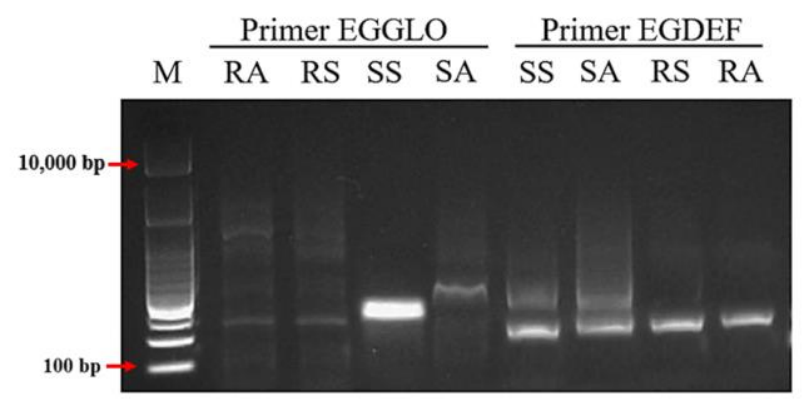

Figure 5. PCR visualization oil palm fruit populations from EGGLO and EGDEF primers. Based on the Hyperladder (100 bp $\sim 10,000 \mathrm{bp}$ ) with $1 \%$ agarose gel.

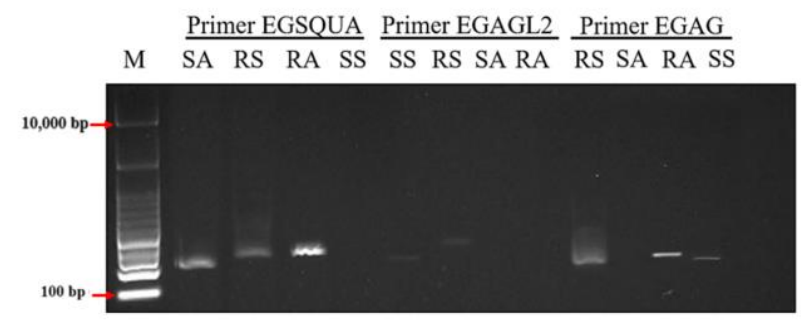

Figure 6. PCR visualization oil palm fruit populations from EGSQUA, EGAGL2 and EGAG primers. Based on the Hyperladder (100 bp 10,000 bp) with 1\% agarose gel 
To suppose the resistance and susceptible population from E. guineensis, the genetic structure used to estimated the genetic distance to obtain the dendrogram. The UPGMA algorithm has described clustering for populations based on genetic distances. The dendrogram was constructed with two cluster groups. The first cluster was described as resistant asymptomatic and symptomatic population. Furthermore, the second cluster consists of two clustering susceptible asymptomatic and symptomatic populations, separately (Figure 7).

Table 3. Na, He and PIC by each population

\begin{tabular}{llll}
\hline Population & Na & He & PIC \\
\hline RA & 2.60 & 0.53 & 0.82 \\
RS & 3.00 & 0.67 & 0.26 \\
SS & 2.20 & 0.40 & 0.42 \\
SA & 2.60 & 0.53 & 0.82 \\
Mean & 2.60 & 0.53 & 0.58 \\
SE & 0.40 & 0.13 & \\
\hline
\end{tabular}

Note: Na: Number of different alleles; He: Expected heterozigosity; PIC: Polymorphic information content. RS: Resistance symptomatic; RA: Resistance asymptomatic; SS: Susceptible symptomatic; SA: Susceptible asymptomatic

Table 4. Frequency by each primer

\begin{tabular}{llll}
\hline Primer & Fit & Fis & Fst \\
\hline EGSQUA & 1.00 & 1.00 & $0.459^{*}$ \\
EGAGL2 & 1.00 & 1.00 & $0.652^{*}$ \\
EGGLO & 1.00 & 1.00 & $0.238^{*}$ \\
EGAG & 1.00 & 1.00 & $0.467^{*}$ \\
EGDEF & 1.00 & 1.00 & $0.273^{*}$ \\
Mean & 1.00 & 1.00 & 0.418 \\
SE & 0 & 0 & 0.075 \\
\hline
\end{tabular}

Note: Wright's statistics. ${ }^{*} \mathrm{P}<0.001$. Fit: Correlations from allele frequency by both factors; Fis: Correlations among individuals from the population of allele frequency; Fst: Correlations among sub-population of allele frequency

\section{UPGMA}

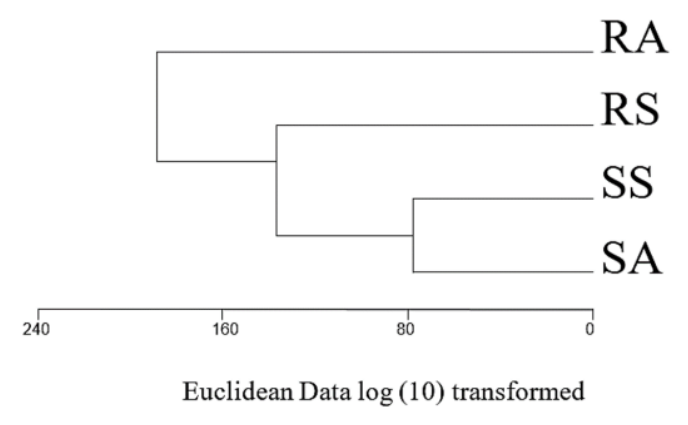

Figure 7. The dendrogram (squared Euclidean, Data-log 10) transformed the genetic distances by pairwise un-weighted clustering (UPGMA), MVSP (ver 3.22) methods. RS: Resistance symptomatic; RA: Resistance asymptomatic; SS: Susceptible symptomatic; SA: Susceptible asymptomatic

\section{Discussion}

PCR visualization of MADS-box genes from oil palm (E. guineensis) to represent allowed to identify distinct among resistance and susceptible to fruits material. The EGSQUA, EGAGL2, EGDEF, EGAG, and EGGLO are respected as potential biomarkers to resistance and susceptible oil palm fruit varieties. In this study, the expression was described to four fruit tissues from resistant and susceptible plants through MADS-box genes.

Different length of genes was identified for each population displayed the single band pattern. Furthermore, the genetic variation is imperative for oil palm populations to be capable to face the present environment changed and to confirm long-term responses to screening and selection for the economic interest of traits. Differentially expressed genes leading to tolerance of Ganoderma have been reported from oil palm (Putranto et al. 2016). In other cases, Adam et al. (2007) have been reported the molecular to flower development of E. guineensis, twelve of MADSbox genes from RT-PCR visualization were founded to determine function spatial and temporal patterns of male and female inflorescences.

MADS-box genes were understood in the determination and evolution of flower fruits from both within the oil palm. A number of different allele was found in $G$. boninense symptom of oil palm at $\mathrm{Na}=3.00$, similarly in this study. Whereas, Bakoumé et al. (2007) have been reported the high intra-populations of diversity oil palm from Ulu Remis Deli not distinct in this study, wherein genetic variety $\mathrm{He}=0.493$ and another case E. oleifera with $\mathrm{He}=0.221$ (Maizura et al. 2017).

The locus showed disjunctive distributions as the value of the allele frequency was not different in Fis and Fit. The allele frequencies both 1.00 signifying deficiency of heterozygotes with significant correration (Fst). Hayati et al. (2004) have been reported the differences in Fst values among oil palm populations in Africa due to restricted gene flow and ecotypic selection among geographic zones.

The dendrogram was constructed based on MADS-Box genes. Closely clusters were estimated due to the sampling rate and the addictive nature of parent crossing derivatives. the resistant symptomatic and the asymptomatic population was found in one cluster, likewise in the susceptible symptomatic and asymptomatic populations.

In conclusion, identification of MADS-box genes acting in development fruits of oil palm type resistance and susceptible to the determination of flowering genetic structure. The results were attained useful for selecting flowering genes although symptoms by Ganoderma greater in genetic diversity.

\section{ACKNOWLEDGEMENTS}

The PMDSU scholarship (Pendidikan Magister Menuju Doktor Untuk Sarjana Unggul) Program (No. 11/AMD/E1/KP.PTNB/2020) supported this study from the Directorate of Research and Community Service, Ministry of Research and Technology and National Research and Innovation Agency, Republic of Indonesia. 


\section{REFERENCES}

Abraham-Juarez MJ, Schrager-Lavelle A, Man J, Whipple CJ, Handakumbura P, Babbitt CC, Bartlett M. 2020. Evolutionary variation in MADS-box dimerization affects floral development and protein degradation dynamics in maize. Plant Cell 11: 3408-3424.

Adam H, Collin M, Richaud F, Beule T, Cros D, Omore A, Nodichao L, Nouy B, Tregear JW. 2011. Environmental regulation of sex determination in oil palm: current knowledge and insights from other species. Ann Bot 108 (8): 1529-1537. DOI: 10.1093/aob/mcr151.

Adam H, Jouannic S, Morcillo F, Richaud F, Duval Y, Tregear JW. 2006 MADS box genes in oil palm (Elaeis guineensis): Patterns in the evolution of the SQUAMOSA, DEFICIENS, GLOBOSA, AGAMOUS, and SEPALLATA subfamilies. J Mol Evol 62 (1): 1531. DOI: 10.1007/s00239-005-0333-7.

Adam H, Jouannic S, Orieux Y, Morcillo F, Richaud F, Duval Y, Tregear JW. 2007. Functional characterization of MADS box genes involved in the determination of oil palm flower structure. J Exp Bot 58 (6): 1245-1259. DOI: 10.1093/jxb/erl263.

Alabi DL, Famakinwa MM, Akinnawonu OE. 2020. Involvement of rural households in oil palm (Elaeis guineensis) fruits postharvest activities in Ondo State, Nigeria. J Agric Ext 24 (1): 42-53.

Alvarez-Buylla ER, Pelaz S, Liljegren SJ, Gold SE, Burgeff C, Ditta GS, Ribas PL, Martinez-Castilla L. 2000. An ancestral MADS-box gene duplication occurred before the divergence of plants and animals. Proc Natl Acad Sci 97 (10): 5328-5333. DOI: 10.1073/pnas.97.10.5328.

Avval SE. 2017. Assessing polymorphism information content (PIC) using SSR molecular markers on local species of Citrullus colocynthis. Case study: Iran, Sistan-Balouchestan province. J Mol Biol Res 7: 42-49.

Bakoumé C, Wickneswari R, Rajanaidu N, Kushairi A, Amblard P, Billotte N. 2007. Allelic diversity of natural oil palm (Elaeis guineensis Jacq.) populations detected by microsatellite markers: implication for conservation. Plant Genet Res 5 (2): 104-107.

Basyuni M, Baba S, Oku, H. 2017. Microsatellite analysis on genetic variation in two populations of red mangrove Rhizophora mangle $\mathrm{L}$. (Rhizophoraceae) and its implication to conservation. IOP Conf Ser Mater Sci Eng 180: 012243.

Breton F, Lubis Z, Rahmaningsih M, Jacquemard JC, Franqueville, H. 2009. A lignified star-shape cavity at root-bole interface: An appropriate culture chamber for Ganoderma boninense and stromaticlike structure development. Intl Oil Palm Conf 12: 556876.

Felsenstein J. 1985. Confidence limits on phylogenies: an approach using the bootstrap. Evolution 39 (4): 783-791. DOI: $10.1111 / \mathrm{j} .1558$ 5646.1985.tb00420.x.

Giovannoni JJ. 2007. Fruit ripening mutants yield insights into ripening control. Curr Opin Plant Biol 10 (3): 283-289.

Hayati A, Wickneswari R, Maizura I, Rajanaidu N. 2004. Genetic diversity of oil palm (Elaeis guineensis Jacq.) germplasm collections from Africa: implications for improvement and conservation of genetic resources. Theor App Genet 108 (7): 1274-1284. DOI: 10.1007/s00122-003-1545-0.

Hayati R, Basyuni M, Chalil D. 2020. Genetic diversity, sequence and bioinformatic analysis of Ganoderma boninense isolates. Intl J Agric Biol 23 (4): 763-770.

Lee PY, Costumbrado J, Hsu CY, Kim YH. 2012. Agarose ge electrophoresis for the separation of DNA fragments. J Vis Exp 62: 3923-3932.

Li SY, Zhang Q, Jin YH, Zou JX, Zheng YS, Li DD. 2020. A MADS-box gene, EgMADS21, negatively regulates EgDGAT2 expression and decreases polyunsaturated fatty acid accumulation in oil palm (Elaeis guineensis Jacq.). Plant Cell Rep 39 (11): 1505-1516. DOI: 10.1007/s00299-020-02579-z.
Lin Z, Cao D, Damaris RN, Yang P. 2020. Genome-wide identification of MADS-box gene family in sacred lotus (Nelumbo nucifera) identifies a SEPALLATA homolog gene involved in floral development. BMC Plant Biol 20: 497. DOI: 10.1186/s12870-020-02712-w.

Low ETL, Azizi N, Halim MA, Sanusi NSNM, Chan KL, Amiruddin N, Manaf MAA. 2020. Oil Palm Genome: Strategies and Applications. The Oil Palm Genome 1: 83-115. Springer, Cham.

Maizura I, Chee-Keng T, Wickneswari R. 2017. Genetic diversity of Elaeis oleifera (HBK) Cortes populations using cross-species SSRs: implication's for germplasm utilization and conservation. BMC Genet 18: 37. DOI: 10.1186/s12863-017-0505-7.

Misron N, Kamal Azhar NS, Hamidon MN, Aris I, Tashiro K, Nagata H. 2020. Effect of charging parameter on fruit battery-based oil palm maturity sensor. Micromachines (Basel) 11 (9): 806. DOI: 10.3390/mi11090806

Noushini S, Park SJ, Jamie I, Jamie J, Taylor P. 2020. Sampling technique biases in the analysis of fruit fly volatiles: A case study of Queensland fruit fly. Sci Rep 10: 19799. DOI: 10.1038/s41598-020-76622-0.

Paterson RRM. 2019. Ganoderma boninense disease deduced from simulation modelling with large data sets of future Malaysian oil palm climate. Phytoparasitica 47: 255-262. DOI: /10.1007/s12600-01900723-4.

Peakall R, Smouse PE. 2006. GENALEX 6: Genetic analysis in Excel. Population genetic software for teaching and research. Mol Ecol Notes 6 (1): 288-295. DOI: 10.1111/j.1471-8286.2005.01155.x

Putranto RA, Syaputra I, Budiani A. 2016. Differential gene expression in oil palm varieties susceptible and tolerant to Ganoderma. Biotechnol Conf 6: 233-243.

Saedler H, Becker A, Winter KU, Kirchner C, Theißen G. 2001. MADSbox genes are involved in floral development and evolution. Acta Biochim Pol 48 (2): 351-358.

Santos CP, Cruz SKD, Batista MC, Germano TA, Costa JH. 2020. Identification and evaluation of reference genes for reliable normalization of real-time quantitative PCR data in acerola fruit, leaf, and flower. Mol Biol Rep 47 (2): 953-965. DOI: 10.1007/s11033019-05187-7

Sarpan N, Taranenko E, Ooi SEE, Low ETL, Espinoza A, Tatarinova TV, Ong-Abdullah M. 2020. DNA methylation changes in clonally propagated oil palm. Plant Cell Rep 39 (9): 1219-1233. DOI: 10.1007/s00299-020-02561-9.

Shahbandeh M. 2020. Production volume of palm oil worldwide from 2012/2013 to 2019/2020. Statista: 613471. https://www.statista.com/

Shariffah-Muzaimah SA, Idris AS, Nur-Rashyeda R, Naidu Y, Zainol NH, Norman K. 2020. Impact of pre-inoculating soil with Streptomyces sp. GanoSA1 on oil palm growth and Ganoderma disease development. Biocatalys Agric Biotech 29: 101814. DOI: 10.1016/j.bcab.2020.101814.

Singh R, Low ETL, Ooi LCL, Ong-Abdullah M, Ting NC, Nookiah, Amiruddin MD. 2020. Variation for heterodimerization and nuclear localization among known and novel oil palm SHELL alleles. New Phytol 226 (2): 426-440. DOI: 10.1111/nph.16387.

Soltis DE, Soltis PS. 1989. Polyploidy, breeding systems and genetic differentiation in homosporous pteridophytes. In: Soltis DE, Soltis PS (eds) Isozymes in Plant Biology. Dioscorides Press, Portland, OR.

Subagyono K. 2020. Palm oil production by province in Indonesia. Directorate General of Estate: 214. http://ditjenbun.pertanian.go.id/.

Uguru MI, Bakoume C, Singh R. 2020. Allelic variability of oil palm inter-population progenies based on simple sequence repeats markers. J Plant Breed Crop Sci 12 (2): 91-96.

Zhu P, Dong T, Xu T, Kang H. 2020. Identification, characterisation, and expression analysis of MADS-box genes in sweet potato wild relative Ipomoea trifida. Acta Physiol Plant 42 (11): 1-13. DOI: 10.1007/s11738-020-03153-6. 